\title{
ANALISIS DETERMINAN OBLIGASI KORPORASI
}

\author{
DETERMINANTS ANALYSIS OF CORPORATE BONDS
}

\section{Gatot Nazir Ahmad")1 dan Wahyudiani*)}

\author{
*) Magister Manajemen, Fakultas Ekonomi, Universitas Negeri Jakarta \\ Jl. Rawamangun Muka, Pulo Gadung, Jakarta 13120
}

\begin{abstract}
This study aims to analyze the effect of interest rates, exchange rates, bond ratings, and DER on yield to maturity of corporate bonds in the Indonesia Stock Exchange for the period 20112014. The analysis technique used panel data analysis. The results of the study show that interest rates (XI) had a positive effect and statistically significant on yield to maturity. The exchange rate (X2) and bond rating (X3) had a negative effect and significant, while DER (X4) had a positive sign and significant. The important finding was the negative relationship of the exchange rate $(X 2)$ to yield to maturity. The negative relationship of the exchange rate occurred because investors perceived that holding rupiah (Rp) currency considered safer than other currencies; hence the rupiah exchange rate against the USD was considered relatively stable. This result was contrary to the basic theory formulated in the hypothesis.
\end{abstract}

Keywords: interest rate, exchange rate, bond rating, DER, panel data

\begin{abstract}
Abstrak: Penelitian ini bertujuan menganalisis pengaruh tingkat suku bunga, nilai tukar, peringkat obligasi dan DER terhadap yield to maturity obligasi korporasi di Bursa Efek Indonesia periode tahun 2011-2014. Teknik analisis yang digunakan yaitu panel data analysis.Hasil penelitian menunjukkan tingkat suku bunga(X1) berpengaruh positif dan signifikan secara secara statistik terhadap yield to maturity. Nilai tukar (X2) dan peringkat obligasi(X3) berpengaruh negatif dan signifikan, sementara DER(X4) berpengaruh positif dan signifikan.Temuan menarik dari penelitian ini yaitu hubungan negatif nilai tukar(X2) terhadap yield to maturity. Hubungan nehatif dari nilai tukar terjadi karena investor memandang memegang rupiah (Rp) dipandang lebih aman daripada mata uang lain sehingga nilai tukar rupiah terhadap USD dianggap masih relatif kuat. Hasil ini berlawanan dengan teori dasar yang diformulasikan dalam hipotesis.
\end{abstract}

Kata kunci: tingkat suku bunga, nilai tukar, peringkat obligasi, DER, panel data

\section{PENDAHULUAN}

Penelitian Blinder (1986) dan West(1986) menunjukkan fenomena berlebihnya inventory menjelaskan volatilitas produksi yang tinggi. Kahn(1987) juga menemukan perilaku yang sama saat varians produksi inventory melebihi varians dari penjualan. Hal ini menunjukkan adanya ketidakpastian permintaan. Keduanya merupakan risiko sistematis dan firmspesific risk yang ditransmisikan melalui hubungan rantai suplai ke mitra bisnis karena kedua jenis risiko ini memengaruhi kebijakan penjualan, produksi, dan inventory perusahaan. Menurut modern asset pricing theory, termasuk capital asset pricing model (CAPM)

${ }^{1}$ Corresponding author:

Email: ahmad72nazir@gmail.com;gnahmad@unj.aci.d oleh Sharpe (1964); Lintner (1965) dan Mossin (1966) serta arbitrage pricing theory (APT) oleh Ross (1976), risiko sistematis terutama menentukan besaran biaya modal perusahaan dan tidak dapat didiversifikasi. Risiko sistematis merupakan komponen utama perusahaan dari risiko bisnis yang merupakan sumber utama risiko kredit perusahaan dan memengaruhi yield obligasi.

Risiko sistematis terkait erat dengan perubahan dalam kondisi ekonomi makro, salah satunya perubahan nilai tukar oleh karena itu studi ini menganalisis pengaruh dari nilai tukar terhadap yield obligasi. Beberapa studi terkait hubungan antara yield obligasi dan nilai tukar, yaitu Pooter et al. (2018), Longstaff dan Schwartz (1995), Collin-Dufresne et al. (2001), Duffie e et al. (2007),Bonfim (2009) serta Tang dan Yan (2010). 
Namun demikian, penelitian tersebut selain terbatas jumlahnya juga hasil penelitiannya berbeda. Perubahan yield (tingkat hasil) obligasi yang diperoleh investor akan mengalami perubahan seiring dengan berjalannya waktu. Perubahan yield tersebut berpengaruh pada tingkat harga pasar obligasi itu sendiri (Samsul, 2006).

Penelitian ini juga menganalisis pengaruh tingkat suku bunga terhadap Yield To Maturity (YTM). Beberapa literatur terkait dengan pengaruh tingkat suku bunga, yaitu Campbell dan Taksler (2003), Collin-Dufresne et al. (2001) yang menyatakan bahwa tingkat suku bunga dapat menjelaskan variasi dari spread obligasi. Risiko perubahan suku bunga dipandang sebagai variabel yang berpengaruh terhadap yield obligasi baik secara teoritis maupun empiris (Kang dan Pflueger, 2015). Riset yang dilakukan oleh Rahman dan Sam'ani (2013) menyatakan BI rate berpengaruh terhadap yield obligasi tidak terbukti. Sebaliknya, Lumbantobing(2014) menyatakan, tingkat suku bunga pasar uang domestik (JIBOR) tidak berpengaruh terhadap YTM obligasi Indonesia. Temuan berbeda yaitu penelitian Ibrahim(2008) yang menunjukkan bahwa tingkat suku bunga berpengaruh positif dan signifikan terhadap YTM obligasi. Dukungan terhadap temuan Ibrahim, yaitu Surya dan Nasher (2011), Purnamawati (2013) serta Idrasih(2013) berpendapat bahwa, tingkat suku bunga (SBI) berpengaruh positif terhadap YTM yang berarti semakin tinggi tingkat suku bunga maka YTM obligasi akan meningkat.

Variabel lain yang juga memengaruhi yield obligasi adalah nilai tukar mata uang Rupiah terhadap US dollar. US dollar sebagai mata uang internasional terkuat dan cukup stabil yang biasanya dipakai sebagai acuan transaksi perusahaan di berbagai negara. Banyak perusahaan menggunakan US dollar sebagai alat transaksi, dan kecenderungan investor membandingkan return yang diterimanya terhadap US dollar. Literatur terdahulu yang menganalisis pengaruh nilai tukar terhadap yield obligasi yaitu Gonzalez-Rozada dan Levy-Yeyati (2008), Longstaff et al. (2011), Jaramillo dan Weber (2013). Penelitian lain mengenai pengaruh nilai tukar rupiah terhadap yield obligasi dilakukan oleh Surya dan Nasher (2011), temuan menunjukkan bahwa nilai tukar memiliki pengaruh positif dan signifikan terhadap yield obligasi. Hasil penelitian Ichsan et al. (2013) juga menunjukkan bahwa nilai tukar rupiah berpengaruh signifikan terhadap nilai obligasi pemerintah di Bursa Efek Indonesia. Hasil penelitian berbeda ditunjukkan oleh Lumbantobing (2014) yang menyatakan tingkat kurs nilai tukar Rp/USD tidak berpengaruh terhadap terhadap YTM obligasi ritel Indonesia.

Obligasi memiliki peringkat kualitas yang mencerminkan probabilitas kegagalannya (Brigham dan Houston, 2001). Pemeringkatan terhadap obligasi dinilai sangat penting karena dapat dimanfaatkan untuk memutuskan apakah obligasi tersebut layak terbit atau tidak serta mengetahui tingkat risikonya (Suliastuti, 2006). Beberapa literatur yang mendukung peringkat obligasi berpengaruh terhadap yield obligasi yaitu Blume et al. (1998), Amato dan Furfine (2004), Jorion et al. (2009), Baghai et al. (2014) serta Xia (2012). Hasil penelitian yang dilakukan oleh Indarsih (2013) menunjukkan bahwa peringkat obligasi tidak berpengaruh signifikan terhadap yield obligasi. Temuan tersebut berbeda dengan penelitian Purnamawati (2013) yang menemukan bahwa peringkat obligasi berpengaruh negatif terhadap yield obligasi.

Debt to equity ratio (DER) merupakan indikator struktur modal dan risiko finansial serta merupakan perbandingan antara hutang dan modal sendiri. Dasar teoriyangdigunakansebagailandasanuntukmenjelaskan hubungan antara DER dan YTM, yaitu agency theory of covenants (ATC) (Jensen dan Meckling, 1976; Myers, 1977; Smith dan Warner, 1979). Bertambah besarnya DER suatu perusahaan menunjukkan risiko distribusi laba usaha perusahaan yang akan terserap untuk melunasi kewajiban perusahaan (Purwanto dan Haryanto,2004). Hasil penelitian yang telah dilakukan oleh Hapsari (2013) menunjukkan bahwa DER berpengaruh terhadap yield to maturity. Temuan Surya dan Nasher(2011) menunjukkan DER berpengaruh positif dan signifikan terhadap yield obligasi.

Berdasarkanuraianyang disampaikandapatdisimpulkan adanya research gap dan theoretical gap, sehingga diperlukan penelitan lebih lanjut mengenai analisis determinan-determinan yang memengaruhi YTM obligasi khususnya obligasi korporasi konvensional non keuangan. Penelitian ini diharapkan berkontribusi dalam pengayaan literatur baik secara teoritis dan empiris. Hal lain yang dapat dikontribusikan dalam penelitian ini yaitu pemilihan locus penelitian yang berbeda dengan topik penelitian sejenis yang selama ini didominasi oleh obligasi negara sehingga diharapkan dapat menjawab gap tersebut. 


\section{METODE PENELITIAN}

Objek Penelitian ini menggunakan sampel semua obligasi korporasi non keuangan yang terdaftar dan diperdagangkan pada periode tahun 2011-2014. Pemilihan sampel dilakukan dengan purposivesampling yaitu metode pemilihan sampel dengan kriteria tertentu dalam hal ini hanya mencakup perusahaan nonkeuangan yang menerbitkan dan memperdagangkan obligasi di Bursa Efek Indonesia. Objek dan sumber data yang digunakan dalam penelitian ini adalah data sekunder yang bersifat kuantitatif, berupa data tingkat suku bunga SBI, data Nilai Tukar USD/IDR, data peringkat obligasi, data rasio DER dan Yield To Maturity Obligasi. Sumber data diperoleh dari Bloomberg, Indonesian Bond Pricing Agency (IBPA), Bursa Efek Indonesia (BEI), website PT. Pefindo dan website Bank Indonesia.

Pada penelitian ini akan menganalisis pengaruh antara tingkat suku bunga, nilai tukar, peringkat obligasi dan DER terhadap Yield To Maturity, dapat dijelaskan dengan sebuah Gambar 1 sebagai Model Hipotesis. Berdasarkan penjelasan teori dari para ahli serta penelitian sebelumnya, maka dapat dibuat suatu rumusan hipotesis sebagai berikut:

H1 : Tingkat Suku Bunga (X1) berpengaruh signifikan dan positif terhadap Yield To Maturity (Y)

H2 : Nilai Tukar (X2) berpengaruh signifikan dan positif terhadap Yield To Maturity (Y)

H3 : Peringkat Obligasi (X3) berpengaruh signifikan dan negatif terhadap Yield To Maturity (Y)

H4 : DER (X4) berpengaruh signifikan dan positif terhadap Yield To Maturity (Y)

Definisi operasional dari masing-masing variabel penelitian sebagai berikut: Yield To Maturity (YTM) merupakan tingkat pengembalian yang akan diperoleh investor pada obligasi jika disimpan hingga jatuh tempo. YTM dihitung dengan rumus sebagai berikut :

$$
Y T M=\frac{C+\frac{F-P_{\text {bond }}}{n}}{\frac{F+P_{\text {bond }}}{2}} \times 100 \%
$$

keterangan: C (Coupon/kupon); F (Face value/nilai nominal); $\mathrm{P}_{\text {bond }}$ (price/harga pasar obligasi); $\mathrm{n}$ (sisa waktu jatuh tempo).
Tingkat suku bunga (interest rate) adalah tingkat suku bunga Sertifikat Bank Indonesia (SBI) 30/hari yang ditetapkan oleh pemerintah. Variabel tingkat suku bunga diberi simbol (IRATE) dan dinyatakan dalam persentase (\%). Kurs (Exchange Rate) adalah harga suatu mata uang terhadap mata uang lainnya atau nilai dari suatu mata uang terhadap nilai mata uang lainnya. Variabel kurs diberi simbol (KURS). Peringkat obligasi adalah pernyataan dalam bentuk simbol tentang keadaaanperusahaan penerbit obligasi yang dikeluarkan oleh PT. PEFINDO, variable peringkat obligasi diberi simbol RATING dan ditentukan denganmenggolongkan peringkat sesuai kategori peringkatnya dengan dummy variabel rating. Variabel RATING dikelompokkan menjadi dua kategori, yaitu Kategori investment grade untuk perusahaan yang risiko defaultnya rendah (Kategori ini dinyatakan dalam peringkat AAA, AA, A, $\mathrm{BBB})$. Ketegori non investment grade untuk perusahaan yang risiko defaultnya tinggi (Kategori ini dinyatakan dalam peringkat $\mathrm{BB}, \mathrm{B}, \mathrm{CCC}, \mathrm{D})$.

Debt to Equity Ratio (DER) adalah perbandingan antara jumlah total hutang terhadap total equity. Rumus untuk menghitung (DER sebagai berikut:

\section{DER $=$ Total Hutang $/$ Total Ekuitas}

Sesuai dengan jenis data yang diperlukan yaitu data sekunder dan teknik sampling yang digunakan, maka pengumpulan data didasarkan pada teknik dokumentasi yang dipublikasikan oleh Bloomberg, Indonesian Bond Pricing Agency (IBPA), Bursa Efek Indonesia (BEI), website PT. Pefindo dan website Bank Indonesia.

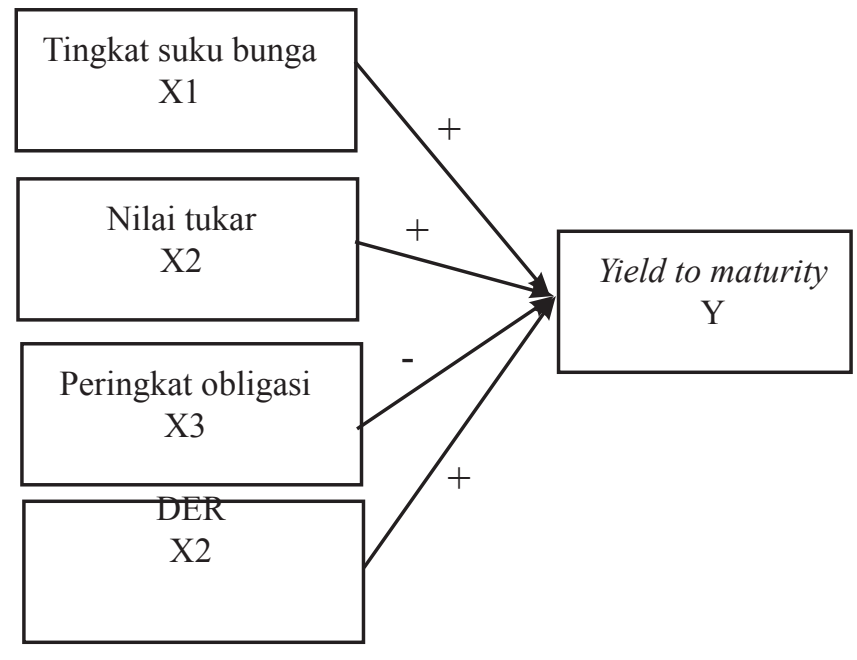

Gambar 1. Model peneliian 
Populasi dan Sample dalam penelitian ini adalah obligasi korporasi konvensional Non Finance yang listed diperdagangkan di Bursa Efek Indonesia (BEI) sampai dengan tahun 2014, yaitu berjumlah 230 perusahaan. Sedangkan metode yang digunakan untuk menentukan sampel dengan metode purposive sampling. Adapun kriteria sampel adalah Obligasi korporasi konvensional Non Finance yang tercatat diperdagangkan selama tahun 2011-2014; Obligasi masih beredar atau belum jatuh tempo sehingga dapat diperoleh dataharga dan YTM obligasi yang berlaku; Membayar kupon dalam jumlah yang tetap, untuk meyakinkan bahwa tidakadanya pengaruh floating rate terhadap yield obligasi; Obligasi perusahaan terdaftar dalam peringkat obligasi yang dikeluarkan oleh Pefindo dengan kategori investment grade; Perusahaan yang menerbitkan obligasi mempunyai laporan keuangan lengkapselama periode pengamatan; Supaya terdapat kesetaraan data maka menggunakan data obligasi yang terdaftar di Bursa Efek Indonesia (BEI).

Pengujian terhadap hipotesis yang diajukan dilakukan dengan metode regresi data panel. Metode regresi data panel digunakan untuk mengetahui pengaruh dari keempat variabel independen terhadap variabel dependen. Adapun persamaan regresi data panel adalah sebagai berikut:

$$
\begin{aligned}
\mathrm{YTM}= & \beta_{0}+\beta_{1} \mathrm{IRATE}_{\mathrm{it}}+\beta_{2} \mathrm{KURS}_{\mathrm{it}}-\beta_{3} \text { RATING }_{\mathrm{it}}+ \\
& \beta_{4} \mathrm{DER}_{\mathrm{it}}+\varepsilon
\end{aligned}
$$

Keterangan: YTM (yield to maturity obligasi); $\beta_{0}$ (konstanta); $\beta_{1}-\beta_{4}$ (koefisien regresi); IRATE (tingkat suku bunga); RATING (peringkat obligasi); KURS (nilai tukar); DER (debt to equity ratio); $\varepsilon$ (residual); $\mathrm{t}$ (waktu); i (perusahaan).

Untuk mengestimasi parameter model dengan data panel, terdapat beberapa teknik yang ditawarkan, yaitu antara lain:

\section{Ordinary Least Square (OLS)}

Teknik ini tidak ubahnya dengan membuat regresi dengan data cross section sebagaimana telah dipelajari sebelumnya. Akan tetapi, untuk data panel, sebelum membuat regresi kita harus menggabungkan data crosssection dengan data time-series (pooldata). Kemudian data gabungan ini diperlakukan sebagai satu kesatuan pengamatan yang digunakan untuk mengestimasi model dengan metode OLS.

\section{Model Efek Tetap (Fixed Effect)}

Adanya variable-variabel yang tidak semuanya masuk dalam persamaan model memungkinkan adanya intercept yang tidak konstan. Atau dengan kata lain, intercept ini mungkin berubah untuk setiap individu dan waktu.Pemikiran inilah yang menjadi dasar pemikiran pembentukan model tersebut.

\section{Model Efek Random (Random Effect)}

Bila pada Model Efek Tetap, perbedaan antar individu dan atau waktu dicerminkan lewat intercept maka pada Model Efek Random, perbedaan tersebut diakomodasi lewat error. Teknik ini juga memperhitungkan bahwa error mungkin berkorelasi sepanjang time series dan cross section.

Dalam hubungan ini, untuk memilih model yang paling tepat digunakan dalam mengelola data panel,terdapat beberapa pengujian yang dapat dilakukan:

\section{Uji Chow}

Chow test, yakni pengujian untuk menentukan model OLS atau Fixed Effect yang paling tepat digunakan dalam mengestimasi data panel. Hipotesis dalam uji chow adalah H0: Common Effect Model atau pooled OLS; H1: Fixed Effect Model.

\section{Uji Hausmann}

Uji Hausmann, yakni pengujian untuk menentukan model Fixed Effect atau Random Effect yang paling tepat digunakan dalam mengestimasi data panel. Hipotesis dalam uji Hausmann adalah H0: Random Effect Model; H1: Fixed Effect Model.

\section{HASIL}

\section{Statistik Deskriptif}

Pada Tabel 1 menunjukkan statistik deskriptif untuk variabel dependen dan independen. Berdasarkan tabel tersebut terlihat dari 44 obligasi korporasi non finance rata-rata memiliki YTM sebesar 9,363353 dengan standar deviasi sebesar 1,080756. Standar deviasi yang cukup kecil ini menunjukkan tidak banyaknya variance atau kesenjangan yang cukup besar. YTM yang terkecil sebesar 6,171404 sampai dengan YTM 
terbesar 13,67873. Rata-rata tingkat suku bunga adalah sebesar 6,676774 dengan standar deviasi sebesar 0,801143 . Dengan standar deviasi yang kecil tersebut menunjukkan bahwa tidak banyaknya variance atau kesenjangan yang cukup besar dari tingkat suku bunga yang terendah sebesar 5,75 dengan tingkat suku bunga yang tertinggi sebesar 7,75 .

Rata-rata RATING (peringkat obligasi) adalah sebesar 4,239173dengan standar deviasi sebesar 2,289215. Standar deviasi yang cukup kecil ini menunjukkan tidak banyaknya variance atau kesenjangan yang cukup besar.Di mana dari RATING (peringkat obligasi) yang terkecil sebesar 0 sampai dengan RATING (peringkat obligasi) terbesar sebesar 8 .

Rata-rata nilai tukar adalah sebesar 10.590,37 dengan standar deviasi sebesar 1.200,288.Dengan standar deviasi yang cukup kecil tersebut menunjukkan bahwa tidak banyaknya variance atau kesenjangan yang cukup besar dari nilai tukar yang terendah sebesar 8.464dengan nilai tukar yang tertinggi sebesar 12.725. Variabel DER (debt to equity ratio) pada Tabel 1 menunjukkan bahwa rata-rata DER adalah sebesar 86,98872 dengan standar deviasi sebesar 51,97232. Standar deviasi yang kecil ini menunjukkan tidak banyaknya variance atau kesenjangan yang cukup besar. DER yang terkecil sebesar 0,339600 sampai dengan DER terbesar sebesar 317,8140.

\section{Uji Model}

\section{Uji Multikolinearitas}

Hasil pengujian data terhadap uji multikolinieritas pada Tabel 2. Dapat dilihat hasil besaran korelasi antar variabel bebas menunjukkan tidak ada korelasi yang kuat antara variabel bebas karena nilai Pearson lebih rendah dari 0,80 .

Tabel 1. Statistik deskriptif

\begin{tabular}{lccccc}
\hline & YTM & Suku_bunga & Rating & Nilai_tukar & DER \\
\hline Mean & 9,363353 & 6,676774 & 4,239173 & 10590,37 & 86,98872 \\
Median & 9,391333 & 6,750000 & 4,000000 & 10263,00 & 91,02229 \\
Maximum & 13,67873 & 7,750000 & 8,000000 & 12725,00 & 317,8140 \\
Minimum & 6,171404 & 5,750000 & 0,000000 & 8464,000 & 0,339600 \\
Std. Dev. & 1,080756 & 0,801143 & 2,289215 & 1200,288 & 51,97232 \\
Skewness & $-0,013853$ & $-0,074280$ & 0,355916 & 0,032196 & 0,684424 \\
Kurtosis & 2,750837 & 1,213457 & 2,336312 & 1,482715 & 4,140412 \\
Observations & 31471 & 31471 & 31471 & 31471 & 31471 \\
\hline
\end{tabular}

\section{Uji Chow}

Hasil uji chow (Tabel 3) menyatakan bahwa model yang terpilih adalah metode Fixed Effect. Hal tersebut dapat dilihat dari nilai probabilitas cross section $\mathrm{F}$ dan cross section Chi square sebesar 0,000000 di mana nilai tersebut lebih kecil dari alpha 0,05 sehingga kita menolak hipotesis nol.

\section{Uji Hausmann}

Dari hasil uji yang telah dilakukan diperoleh kesimpulan bahwa model tidak mengikuti Pool Effect namun mengikuti Fixed Effect. Berdasarkan hal tersebut maka langkah analisa data dilanjutkan kembali dengan uji hausmann. Dari Tabel 4 dapat kita lihat bahwa nilai cross section random sebesar 0,0082 . Nilai tersebut lebih kecil dari nilai alpha 0,05 sehingga model yang terpilih tetap menggunakan metode Fixed Effect.

\section{Uji Hipotesis}

Berdasarkan pada Tabel 5 maka dapat disimpulkan mengenai pengujian hipotesis sebagai berikut:

\section{Hipotesis 1}

Tingkat suku bunga berpengaruh positif dan signifikan terhadapYTM obligasi. Berdasarkan hasil pengujian hipotesis 1 tersebut pada Tabel 5 menunjukkan bahwa variabel tingkat suku bunga secara statistik signifikan pada $\alpha=0,05$,sedangkan nilai t hitung sebesar 92,16815 dan t tabel 2,023 (t hitung $>$ t tabel) sehinggaberdasarkan hasil tersebut maka hipotesis 1 diterima. Dengan demikian, maka sesuai dengan hipotesis atau tanda koefisien yang positif menunjukkan bahwa semakin tinggi tingkat suku bunga maka YTM obligasi akan meningkat (semakin besar). 
Tabel 2. Uji multikolinieritas

\begin{tabular}{lcccc}
\hline & Suku_bunga & Rating & Nilai_tukar & DER \\
\hline Suku_bunga & 1,000000 & $-0,014439$ & 0,728867 & 0,109421 \\
Rating & $-0,014439$ & 1,000000 & $-0,021796$ & $-0,009160$ \\
Nilai_tukar & 0,728867 & $-0,021796$ & 1,000000 & 0,177315 \\
DER & 0,109421 & $-0,009160$ & 0,177315 & 1,000000 \\
\hline
\end{tabular}

Tabel 3. Chow test

\begin{tabular}{llll}
\hline Effects Test & Statistic & d.f. & Prob. \\
\hline Cross-section F & 681,424378 & $(43,31424)$ & 0,0000 \\
Cross-section Chi-square & 20732,705539 & 43 & 0,0000 \\
\hline
\end{tabular}

Tabel 4. Hausman test

\begin{tabular}{llcl}
\hline Test Summary & Chi-Sq. Statistic & Chi-Sq. d.f. & Prob. \\
\hline Cross-section random & 11,765234 & 3 & 0,0082 \\
\hline
\end{tabular}

Hasil pengujian menunjukkan pengaruh positif dan signifikan antara tingkat suku bunga terhadap yield obligasi (menerima hipotesis 1). Di mana nilai p-value yang dihasilkan lebih kecil dari 0,05 yaitu sebesar 0,000 dan memiliki arah koefisien regresi yang positif yaitu sebesar 0,905. Temuan menunjukkan bahwa apabila terjadi kenaikan pada tingkat suku bunga SBI maka akan mengakibatkan kenaikan yield obligasi. Ini sesuai dengan teori yang dikemukakan oleh Horne dan Wachowicz (1997) yang menyatakan jika tingkat bunga meningkat maka tingkat pengembalian yang diharapkan pasar juga meningkat sehingga harga obligasi akan menurun. Temuan penelitian ini juga didukung oleh Ibrahim (2008), Indarsih (2013), Purnamawati (2013), Surya dan Nasher(2011),Ichsan et al. (2013), Kadir(2007) yang menyatakan bahwa kenaikan pada BI rate maka akan mengakibatkan kenaikan yield obligasi. Namun, terdapat temuan berbeda pada penelitian Nurfauziah et al. (2004) serta Rahman dan Sam'ani(2013) yang menunjukkan bahwa BI rate tidak berpengaruh terhadap YTM obligasi.

\section{Hipotesis 2}

Nilai tukar berpengaruh negatif dan signifikan terhadap YTM obligasi. Berdasarkan hasil pengujian hipotesis 2 tersebut pada Tabel 5 menunjukkan bahwa variabel nilai tukar secara statistik signifikan pada $\alpha=0,05$, sedangkan nilai $t$ hitung sebesar $-12,220$ dan $t$ tabel 2,023 ( $\mathrm{t}$ hitung $>\mathrm{t}$ tabel) sehingga berdasarkan hasil tersebut bahwa ada pengaruh signifikan nilai tukar terhadap yield obligasi terbukti tetapi dengan arah yang bernilai negatif.

Hasil hipotesis dua menunjukkan bahwa terdapat pengaruh negatif dan signifikan dari nilai tukar terhadap yield obligasi. Temuan ini tidak sesuai dengan hipotesis dua yang dirumuskan yaitu nilai tukar berpengaruh positif dan signifikan terhadap yield obligasi. Menurut Levi (2001), kontribusi kurs terhadap yield obligasi jauh lebih besar daripada terhadap saham. Depresiasi mata uang rupiah dapat mendorong pemerintah untuk meningkatkan tingkat bunga dalam usaha mendongkrak nilai mata uang, praktek ini disebut leaning against the wind. Tingkat bunga yang lebih tinggi akan menurunkan harga obligasi dalam mata uang lokal, sehingga depresiasi mata uang diikuti dengan penurunan nilai obligasi dalam mata uang lokal.

Temuan penelitian ini sejalan dengan penelitian yang dilakukan oleh Advisindo (2006) di mana kurs berpengaruh negatif signifikan terhadap yield obligasi. Temuan ini didukung oleh hasil penelitian Aditya et al.(2018), Rahman dan Sam'ani (2013) dan Lumbantobing (2014) yang menyebutkan bahwa terjadi hubungan negatif di mana jika kurs semakin naik maka harga obligasi akan naik dan yield obligasi akan semakin rendah atau turun.Hasil penelitian berbeda diperoleh Surya dan Nasher (2011) yang mendapatkan bahwa kurs memiliki hubungan yang positif dan signifikan dengan dengan yield obligasi. 
Hipotesis 3

Rating (peringkat obligasi) berpengaruh negatif dan signifikanterhadap YTM obligasi. Berdasarkan hasil pengujian hipotesis 3 tersebut pada Tabel 5 menunjukkan bahwa variabel RATING (peringkat obligasi) secara statistik signifikan pada $\alpha=0,05$ sedangkan nilai t hitung sebesar $-97,56725$ dan t tabel 2,023 ( $\mathrm{t}$ hitung $>\mathrm{t}$ tabel) sehingga berdasarkan hasil tersebut maka hipotesis 3 diterima. Dengan demikian, maka sesuai dengan hipotesis atau tanda koefisien yang negatif menunjukkan bahwasemakin tinggi RATING (peringkat obligasi) maka YTM obligasi akan menurun (semakin kecil).

Temuan penelitian menunjukkan bahwa peringkat obligasi berpengaruh negatif terhadap yield obligasi. Menurut Brigham dan Houston (2010), peringkat obligasi memiliki arti penting bagi perusahaan dan investor.Pertama, karena peringkat obligasi merupakan indikator dari risiko gagal bayarnya, peringkat memiliki pengaruh langsung yang dapat diukur pada tingkat bunga obligasi dan biaya utang perusahaan.Kedua, sebagian besar obligasi dibeli oleh investor institusional dan bukan individual, kebanykan institusi dibatasi hanya oleh membeli efek yang layak investasi.Karena risiko yang lebih tinggi dan pasar yang terbatas, obligasi berperingkat rendah memiliki tingkat pengembalian diminta yang lebih tinggi, dibandingkan obligasi berperingkat tinggi. Hasil penelitian sejalan dengan temuan Purnamawati (2013) dan Ibrahim (2008) yang menunjukkan bahwa rating obligasi memiliki hubungan negatif dengan yield obligasi. Namun, temuan berbeda dengan hasil penelitian Indarsih (2013) yaitu peringkat obligasi tidak berpengaruh signifikan terhadap yield obligasi dikarenakan peringkat obligasi cenderung tidak mengalami perubahan atau tetap untuk jangka waktu yang relatif lama dibandingkan dengan maturity obligasinya.

\section{Hipotesis 4}

Debt to Equity Ratio (DER) berpengaruh positif dan signifikan terhadap YTM obligasi. Berdasarkan hasil pengujian hipotesis 4 tersebut pada Tabel 5 menunjukkan bahwa variabel DER secara statistik signifikan pada $\alpha=$ 0,05 sedangkan nilai thitung sebesar 64,7534 dan $t$ tabel 2,023 ( $\mathrm{t}$ hitung $>\mathrm{t}$ tabel) sehingga berdasarkan hasil tersebut maka hipotesis 4 diterima. Dengan demikian, maka sesuai dengan hipotesis atau tanda koefisien yang positif menunjukkan bahwa semakin besar DER maka YTM obligasi akan meningkat (semakin besar).

Hasil penelitian membuktikan bahwa DRE berpengaruh positif dan signifikan secara statistik terhadap yield obligasi. Tingkat DER mencerminkan level risiko default yang dimiliki oleh perusahaan yang berarti semakin tinggi DER maka risiko default perusahaan di masa mendatang semakin besar. Tingginya DER akan berimplikasikepada tingginya yield yang dipersyaratkan oleh investor. Temuan penelitian ini didukung oleh Hapsari (2013), Surya dan Nasher (2011) dan Ibrahim (2008) serta Bhojraj dan Sengupta (2003).

Tabel 5. Uji hipotesis

\begin{tabular}{lcccc}
\hline Variable & Coefficient & Std. Error & t-Statistic & Prob. \\
\hline C & 4,467318 & 0,037246 & 119,9417 & 0,0000 \\
SUKU_BUNGA & 0,905775 & 0,009827 & 92,16815 & 0,0000 \\
RATING & $-0,170391$ & 0,001746 & $-97,56725$ & 0,0000 \\
NILAI_TUKAR & $-8,08 \mathrm{E}-05$ & $6,61 \mathrm{E}-06$ & $-12,22010$ & 0,0000 \\
DER & 0,004898 & $7,56 \mathrm{E}-05$ & 64,75354 & 0,0000 \\
\hline R-squared & 0,587664 & Mean dependent var & & 1,080756353 \\
Adjusted R-squared & 0,587612 & S.D. dependent var & & 2,107568 \\
S.E. of regression & 0,694034 & Akaike info criterion & & 2,108895 \\
Sum squared resid & 15156,65 & Schwarz criterion & & 2,107993 \\
Log likelihood & $-33158,63$ & Hannan-Quinn criter & & 0,022238 \\
F-statistic & 11211,40 & Durbin-Watson stat & & \\
Prob (F-statistic) & 0,000000 & & & \\
\hline
\end{tabular}


Temuan menarik dari penelitian ini, yaitu diperolehnya hubungan negatif antara nilai tukar dengan yield obligasi. Temuan ini didapatkan karena Indonesia masih dianggap sebagai salah satu alternatif investasi yang lebih menguntungkan dibandingkan dengan beberapa negara sekitar oleh para investor asing. Berdasarkan perkembangan Yield obligasi Government yang jatuh tempo 5 tahun dan 10 (Gambar 1) Indonesia masih memberikan return investasi lebih baik dibandingkan Malaysia, Thailand dan Filipina. Hal yang serupa berlaku untuk nilai tukar, fluktuasi perubahan nilai tukar rupiah dari awal tahun 2011 sampai dengan pertengahan tahun 2013 relatif lebih kecil dibandingkan dengan negara ASEAN, hal tersebut menunjukkan bahwa nilai tukar rupiah lebih stabil dibandingkan nilai tukar di beberapa negara sekitar (Gambar 2).

\section{Implikasi Manajerial}

Investor selayaknya mempertimbangkan atau memonitor pergerakan dari tingkat suku bunga SBI, dimana apabila tingkat suku bunga SBI mengalami kenaikan maka merupakan waktu yang tepat untuk membeli obligasi dan waktu yang tidak tepat untuk merealisasikan capital gain sehingga sebaiknya investor menahan obligasi. Sebaliknya, apabila tingkat suku bunga SBI mengalami penurunan maka merupakan waktu yang tepat untuk menjual obligasi atau merealisasikan capital gain. Bagi investor yang risk taker dan ingin berinvestasi pada obligasi maka sebaiknya membeli obligasi yang memiliki rating yang rendah karena akan menawarkan yield yang tinggi, sedangkan bagi investor yang risk averter maka sebaiknya membeli obligasi yang memiliki rating yang tinggi karena memiliki risiko default yang rendah akan tetapi menawarkan yield yang rendah. Selain itu, investor yang risk taker sebaiknya berinvestasi pada obligasi yang dikeluarkan oleh emiten obligasi yang memiliki DER yang besar karena akan memberikan yield yang besar. Bagi investor yang risk averter maka sebaiknya berinvestasi pada obligasi yang dikeluarkan oleh emiten obligasi yang memiliki rasio DER yang kecil, karena memiliki risiko default yang relatif lebih kecil.

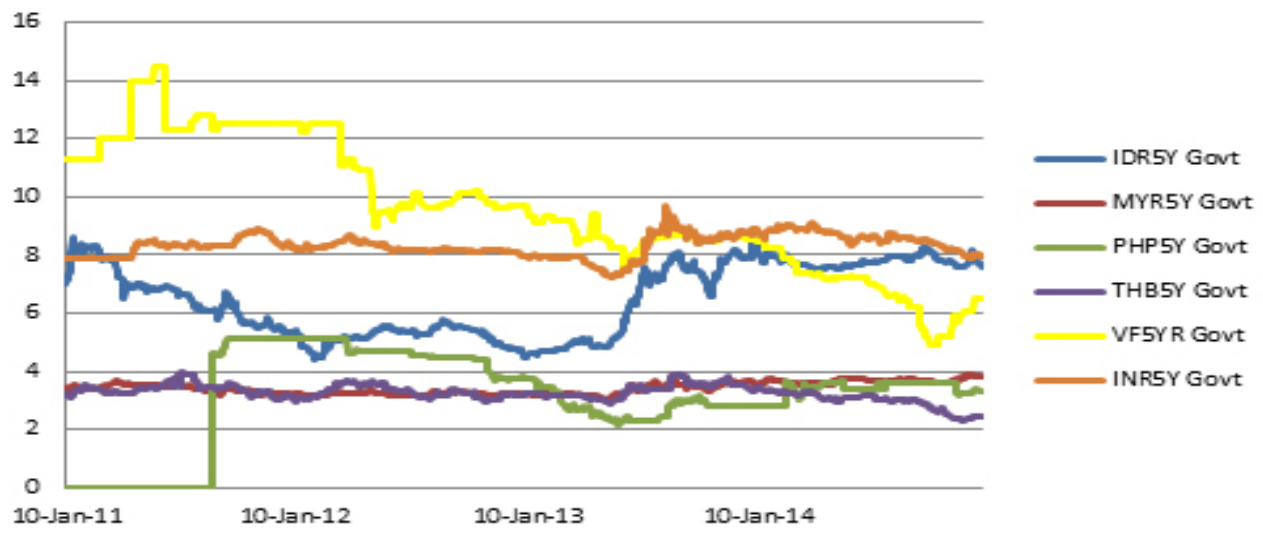

Gambar 1. Perkembangan Yield obligasi Government

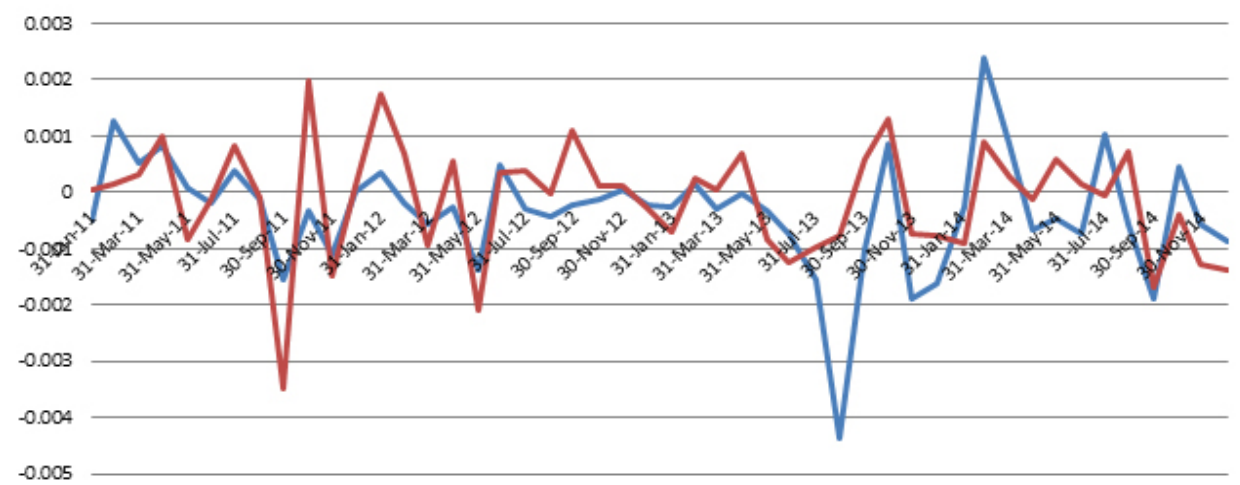

-IDR Curncy MYR Curncy

Gambar 2. Nilai Tukar Indonesia vs Malaysia (IDR vs MYR) 


\section{KESIMPULAN DAN SARAN}

\section{Kesimpulan}

Yield to maturity (YTM) obligasi korporasi dipengaruhi faktor makroekonomi, yaitu tingkat suku bunga serta nilai tukar rupiah terhadap dollar amerika. Pengaruh faktor makroekonomi ini berbeda, untuk tingkat suku bunga positif sedangkan nilai tukar negatif. Selain itu faktor internal dalam perusahaan yang berpengaruh terhadap YTM, yaitu peringkat obligasi dan DER. Temuan penting dalam penelitian ini yaitu pengaruh negatifdari nilai tukar terhadap YTM karena berlawanan dengan hipotesis yang diformulasikan.

\section{Saran}

Dalam berinvestasi obligasi korporasi, investor perlu memahami sekaligus mengetahui market timing yaitu kapan saat beli obligasi dan kapan saat jual obligasi karena hal ini akan berpengaruh kepada tingkat keuntungan obligasi yang akan diraih. Hal yang lainnya yaitu terkait dengan preferensi terhadap risiko yang berbeda pada setiap investor, misalnya investor yang memiliki karakter risk taker akan memilih obligasi yang memiliki rating yang rendah karena memberikan yield yang tinggi. Selain hal tersebut, untuk memperkuat penelitian lanjutan perlu adanya penambahan teori lainnya yang diduga kuat relevan dengan analisis obligasi seperti planned behavior. Hal yang lainnya yaitu penambahan periode penelitian agar hasilnya lebih dapat mewakili kondisi yang ada dengan menggunakan sampel yang lebih besar dan menambah variabel atau determinan lain yang diduga memengaruhi yield obligasi seperti biaya transaksi.

\section{DAFTAR PUSTAKA}

Aditya, Sinaga BM, Maulana TBA. 2018.Pengaruh indeks bursa luar negeri,indikator makroekonomi dan krisis ekonomi global terhadap indeks harga saham gabungan di Indonesia.Jurnal Aplikasi Bisnis dan Manajemen 4(2):159-170. https:// doi.org/10.17358/jabm.4.2.284.

Advisindo AA .2006. Fixed Income Research.Biweekly Report.

Amato JD,Furfine CH.2004.Are credit ratings procyclical?.Journal of Banking and Finance 28(11):2641-2677.https://doi.org/10.1016/j. jbankfin.2004.06.005.
Baghai RP,Servaes H, Tamayo A.2014. Have rating agencies become more conservative? implications for capital structure and debt pricing. Journal of Finance 69(5):1961-2005. https://doi.org/10.1111/jofi.12153.

Baltagi BH. 2008. Econometrics 4th edition. Springer:Verlag Berlin Heidelberg.

Blinder AS.1986.Can the production smoothing model of inventory behavior be saved?. The Quarterly Journal of Economics 101(3):431-454.https:// doi.org/10.2307/1885691.

Blume ME,Lim F,MacKinlay AC. 1998.The declining credit quality of u.s. corporate debt: myth or reality?. Journal of Finance 53(4):1389-1413. https://doi.org/10.1111/0022-1082.00057.

Bodie Z, Kane A,Markus AJ. 2004.Manajemen Portofolio dan Investasi Edisi Kesembilan, Buku Satu. Jakarta: Salemba Empat.

Bodie Z, Kane A, Markus AJ.2006. Investasi, Buku 2, Edisi 6. Jakarta: Salemba Empat.

Bonfim D.2009. Credit risk drivers: evaluating the contribution of firm level information and of macroeconomic dynamics. Journal of Banking and Finance 33 (2):281-299. https://doi. org/10.1016/j.jbankfin.2008.08.006.

Brigham EF, Houston JF. 2010. Dasar-Dasar Manajemen Keuangan Edisi 11 Buku 1,Salemba Empat, Jakarta.

Brigham EF,Houston JF.2001. Manajemen Keuangan Edisi 8 Buku I, Penerbit Erlangga, Jakarta.

Campbell JY,Taksler GB.2003. Equity volatility and corporate bond yields. Journal of Finance 58(6):2321-2349.https://doi.org/10.1046/ j.1540-6261.2003.00607.x.

Cavallo EA, Valenzuela P. 2010.The determinants of corporate risk in emerging markets: an option -adjusted spread analysis. International Journal of Finance and Economics 15(1): 59-74. https:// doi.org/10.1002/ijfe.398.

Duffie D,Saita L, Wang K. 2007.Multi-period corporate default prediction with stochastic covariates. Journal of Financial Economics 83 (3):635-665. https://doi.org/10.1016/j.jineco.2005.10.011.

Dufresne PC, Goldstein RS, Martin JS.2001.The determinants of credit spread changes. Journal of Finance 56 (6):2177-2207. https://doi. org/10.1111/0022-1082.00402.

Elton EJ,Gruber MJ,Agrawal D.2001.Explaining the rate spread on corporate bonds. Journal of Finance 56(1):247-277. https://doi.org/10.1111/00221082.00324 . 
Fabozzi FJ. 2000.Manajemen Investasi, Edisi Pertama. Jakarta: Salemba Empat.

Fabozzi FJ.2004.Bond Market, Analysis and Strategies, 5th edition. UK: Prentice Hall International Editions.

Francis JK, Richard WT.1992. Schaum's Outline of Investment. Mc Graw Hill Inc: New York

Gabbi G, Sironi A.2005. Which factors affect corporate bond pricing? empirical evidence from eurobonds primary market spreads. European Journal of Finance 11(1):59-74. https://doi.org/10.1080/1 351847032000143422.

Gadanecz B,Ken M, Shu C.2014. Exchange rate risk and local currency sovereign bond yields in emerging markets. BIS Working Papers No 474. Bank for International Settlements.

Gonzalez-Rozada M, Levy-Yeyati E.2008.Global factors and emerging market spreads. The Economic Journal 118(553):1917-1936.https:// doi.org/10.1111/j.1468-0297.2008.02196.x.

Gujarati DN, Porter DC.2010. Dasar-dasar Ekonometrika, Buku 1 Edisi 5.. Jakarta: Salemba Empat.

Gumanti TA.2007.Bauran pendanaan, prinsip keuangan dan siklus kehidupan perusahaan. Manajemen Usahawan Indonesia 2:41-48.

Hamid A, Rodoni A, Warninda TD, Hidayat E.2006. Analisis durasi dan convexity untuk mengukur sensitivitas harga obligasi korporasi terhadap perubahan tingkat suku bunga (studi empiris pada obligasi - obligasi di Indonesia. Jurnal Maksi 6(2):117-142.

Hapsari RA.2013.Kajian yield to maturity (YTM) obligasi pada perusahaan korporasi. Accounting Analysis Journal 2(1):75-81.

Husnan S. 2000.Manajemen Keuangan Teori dan Penerapan (Keputusan Jangka Panjang). Yogyakarta: BPFE.

Ibrahim H.2008.Pengaruh tingkat suku bunga, peringkat obligasi, ukuran perusahaan, dan der terhadap yield obligasi korporasi di bursa efek Indonesia 2004-2006 [tesis]. Semarang: Universitas Diponegoro.

Ichsan,Syamni G, Nurlela,Rahman A.2013.Dampak BI rate, tingkat suku bunga, nilai tukar, dan inflasi terhadap nilai obligasi pemerintah. Jurnal Keuangan dan Perbankan 17(2):310-322.

Indarsih N. 2013. Pengaruh tingkat suku bunga sbi, rating, likuiditas, dan maturitas terhadap yield to maturity obligasi. Jurnal Ilmu Manajemen
1(1):125-136.

Indrawati KK. 2003. Pengaruh Quick Ratio, EBIT per Total Debt, ROE,DER, Debt dan Durasi terhadap Return Obligasi Korporasi Indonesia. Surabaya:Universitas Kristen Petra.

Jaramillo L, Weber A.2013.Bond yields in emerging economies: it matters what state you are in. Emerging Markets Review 17(1):169-185. https://doi.org/10.1016/j.ememar.2013.09.003.

Jaramillo L,Weber A.2013.Global spillovers into domestic bond markets in emerging market economies. IMF Working Paper 13/264.https:// doi.org/10.5089/9781484328446.001.

Jensen M C, Meckling WH.1976.Theory of the firm: managerial behavior, agency costs, and capital structure. Journal of Financial Economics 3(4):305-360. https://doi.org/10.1016/0304405X(76)90026-X.

Jewell J,MB Livingston.2000.The impact of a third credit rating on pricing of bond. The Journal of Fixed Income 10(3):69-85. https://doi. org/10.3905/jfi.2000.319275.

Jorion P,Shi C, Zhang S.2009. Tightening credit standards: the role of accounting quality. Review of Accounting Studies 14(1):123-160.https://doi. org/10.1007/s11142-007-9054-z.

Kahn JA.1987.Inventories and the volatility of production. American Economic Review 77(4):667-679.

Kang J ,Pflueger C.2015.Inflation risk in corporate bonds.Journal of Finance 70(1):115-162.https:// doi.org/10.1111/jofi.12195.

Keown AJ, Martin JD, Petty JW, Scott DF.2004. Manajemen Keuangan: Prinsip-prinsip dan Aplikasi, Jilid 1, Edisi Kesembilan. Jakarta: PT. Indeks.

Kusuma H, Asrori.2005.Pengaruh durasi dan konveksitas terhadap sensitivitas harga obligasi. Sinergi I 7(2):35-52.

Levi MD.2001. Keuangan Internasional. Yogyakarta: Penerbit Andi.

Lintner J.1965. The valuation of risk assets and selection of risky investments in stock portfolios and capital budgets. The Review of Economic Statistics 47(1):13-37. https://doi.org/10.2307/1924119.

LongstaffFA,Pan J,Pedersen L,Singleton KJ.2011.How sovereign is sovereign credit risk?.American Economic Journal: Macroeconomics 3(2):75103. https://doi.org/10.1257/mac.3.2.75.

Longstaff FA, Schwartz ES .1995. A simple approach 
to valuing risky fixed and floating rate debt. Journal of Finance 50(3):789-819. https://doi. org/10.1111/j.1540-6261.1995.tb04037.x.

Lumbantobing AL.2014.Pengaruh inflasi, nilai tukar rupiah, suku bunga pasar uang domestik dan suku bunga pasar luar negeri terhadap yield to maturity obligasi ritel indonesia di bursa antar bank periode 2010-2013. Jurnal MIX 4(2):151173.

Mossin J.1966.Equilibrium in a capital market. Econometrica 34(4):768-783. https://doi. org/10.2307/1910098.

Myers S C.1977. Determinants of corporate borrowing. Journal of Financial Economics 5(2):145-147. https://doi.org/10.1016/0304-405X(77)90015-0.

Nachrowi DN.2006.Pendekatan Populer dan Praktis Ekonometrika Untuk Analisis Ekonomi dan Keuangan. Jakarta: Lembaga Penerbit Fakultas Ekonomi Universitas Indonesia.

Nainggolan P,Hanum L.2005. Prediksi gagal bayar obligasi tahun 1998-2004 dengan analisis diskriminan dan regresi logistik. Jurnal Bisnis \& Manajemen 5(2):79-90.

Nurfauziah N, Setyarini AF.2004.Analisis faktor-faktor yang memengaruhi yield obligasi perusahaan (studi kasus pada industri perbankandan industri finansial). Jurnal Siasat Bisnis 2(9):241-256. https://doi.org/10.20885/jsb.vol2.iss9.art6.

Pooter MD,Martin RF,Pruitt S.2018.The liquidity effects of official bond market intervention. Journal of Financial and Quantitative Analysis 53(1):243-268.https://doi.org/10.1017/ S0022109017000898.

Priambodo REA.2006.Relevansi ORI Secara Makro dan Mikro. Usahawan, No. 11, TH. XXXV, November:42-47.

Purnamawati IGA.2013.Pengaruh peringkat obligasi, tingkat suku bunga sertifikat bank indonesia, rasio leverage, ukuran perusahaan dan umur obligasi pada imbal hasil obligasi korporasi di bursa efek indonesia. VOKASI Jurnal Riset Akutansi 2(1):28-45.

Purwanto A, Haryanto.2004.Pengaruh perkembangan informasi rasio laporan keuangan terhadap fluktuasi harga saham dan tingkat keuntungan saham.Jurnal Akuntansi \& Auditing 1(1):17-33.

Rahardjo S.2003.Panduan Investasi Obligasi. Jakarta: PT. Gramedia Pustaka Utama.

Rahman AA, Sam'ani.2013.Analisis faktor-faktor yang memengaruhi yield obligasi negara tahun 20102012.JurnalEkonomi-Manajemen-Akutansi
20(35):1-16.

Ratih SD.2006.Saham dan Obligasi, Edisi Pertama, Cetakan Kedua.Yogyakarta: Penerbit UAJY.

Rizzi JV.1994.Determining debt capacity.Commercial Lending Review 2:25-34.

Ross S.1976.The arbitrage theory of capital asset pricing. Journal of Economic Theory 13(3):341-360. https://doi.org/10.1016/0022-0531(76)90046-6.

Samsul M.2006. Pasar Modal \& Manajemen Portofolio. Jakarta: Penerbit Erlangga.

Sanjeev B, Sengupta P.2003.Effect of corporate governance on bond ratings an yields : the role of institutional investors and outside director. Journal of Business 76(3):455-475. https://doi. org/10.1086/344114.

Setyapurnama RYS. 2005. Pengaruh Corporate Governance dan Kualitas Audit Terhadap Peringkat dan Yield Obligasi [Tesis, Tidak dipublikasikan]. Yogyakarta: Program Ilmu Akuntansi, UGM.

Sharpe WF. 1964.Capital asset prices: a theory of market equilibrium under conditions of risk. Journal of Finance 19(3):425-442. https://doi. org/10.1111/j.1540-6261.1964.tb02865.x

Sharpe WF, Gordon, Bailey AJ.2005. Investasi, Edisi Keenam, Jilid 10. Jakarta: PT. Indeks Kelompok Gramedia.

Smith CW, Warner J B.1979. On financial contracting: an analysis of bond covenants. Journal of Financial Economics 7(2):117-161. https://doi. org/10.1016/0304-405X(79)90011-4.

Suharli M.2005. Studi empiris terhadap dua faktor yang memengaruhi returnsaham pada industri food \& beverages di bursa efek Jakarta. Jurnal Akuntansi dan Keuangan 7(2):99-116.

Suliyanto.2011.Ekonometrika Terapan: Teori \& Aplikasi dengan SPSS. Yogyakarta: Andi.

Surya BA, Nasher TG. 2011. Analisis pengaruh tingkat suku bunga sbi, exchange rate, ukuran perusahaan, debt to equity ratio dan bond terhadap yield obligasi korporasi di indonesia. Jurnal Manajemen Teknologi 10(2):186-195.

Susilowati L,Sumarto.2010. Memprediksi tingkat obligasi perusahaan manufaktur yang listing di bei. Jurnal Mitra Ekonomi dan Manajemen Bisnis 1(2):163-175.

Tandelilin E.2007. Analisis Investasi dan Manajemen Portofolio, Edisi Pertama, Cetakan Kedua. Yodgyakarta: BPFE.

Tang DY,Yan H.2010. Market conditions, default risk and credit spreads.Journal of Banking 
and Finance 34(4):743-753. https://doi. org/10.1016/j.jbankfin.2009.05.018.

Van Horne JC,Wachowicz JM.1997. Prinsip - Prinsip Manajemen Keuangan, Edisi Kesembilan, Buku Satu. Jakarta: Salemba Empat.

Wallace RSO,Naser K, Mora A.1994. The relationship between the comprehensiveness of corporate annual reports and firm characteristics in Spain. Accounting \& Business Research 25(97):41-53. https://doi.org/10.1080/00014788.1994.972992 7.
West KD. 1986.A Variance bounds test of the linear quadratic inventory model. Journal of Political Economy 94(2):374-401. https://doi. org/10.1086/261378.

Weston JF,Copeland TE.1994.Manajemen Keuangan, Jilid 1, Edisi Kedelapan. Jakarta: Penerbit Erlangga.

Xia H.2012. Can competition improve the information quality of credit ratings? Working Paper, University of Texas at Dallas.https://doi. org/10.2139/ssrn.1981516. 